\title{
Comparing Agricultural Conservation Planning Framework (ACPF) practice placements for runoff mitigation and controlled drainage among 32 watersheds representing lowa landscapes
}

\author{
M.D. Tomer, J.D. Van Horn, S.A. Porter, D.E. James, and J. Niemi
}

\begin{abstract}
Precision conservation planning tools can use high-resolution data to identify conservation practice-placement options for watershed improvement plans. Use of these tools across multiple watersheds could help to identify regional conservation strategies. This study evaluated practice-placement options determined using the Agricultural Conservation Planning Framework (ACPF) ArcGIS tools for controlled drainage (CD), contour buffer strips (CBS), water and sediment control basins (WASCOBs), and grassed waterways (GWWs) across 32 headwater hydrological unit code (HUC)12 watersheds in Iowa. The watersheds represented three Major Land Resource Areas (MLRAs) and four AgroHydrologic Landscape (AHL) classes, with four watersheds randomly chosen from each of eight combined MLRA-AHL landscape groupings. Placement options for the practices identified using the ACPF were quantified by watershed as densities ( $\mathrm{km} \mathrm{km}^{-2}$ of cropland) for GWWs, counts of proposed practice locations per square kilometer for CBS and WASCOBs, and as fractions of tile-drained land for CD. The influence of the landscape groupings on practice-placement densities among watersheds was tested using analysis of variance and contrast comparisons. Significant differences were found that led to nuanced interpretations. Differences attributed to slope steepness were captured by AHL classes, while differences attributed to slope shape and convergence were best captured by MLRA, which better segregated the watersheds based on landscape age and stream dissection. Grassed waterway placements showed minor differences among MLRAs but provided data to better inform the choices that ACPF users can make when running the GWW tool. The MLRA/AHL landscape classifications could be used together to develop effective regional conservation strategies using precision planning tools.
\end{abstract}

Key words: cross-watershed research-Major Land Resource Areas-precision conservationwatershed conservation

A variety of conservation practices are designed to detain runoff water so that natural processes (i.e., settling, adsorption, uptake, and transformation) can decrease the amounts of nutrients, sediment, and other contaminants carried in runoff from agricultural landscapes. The choice of practices is critical in conservation planning because it allows conservation

Received December 21, 2018; Revised September 20, 2019; Accepted September 24, 2019; Published online April 25, 2020. measuring water quality improvements following implementation. Nevertheless, understanding the relative effectiveness of different conservation practices is necessary to assess planning alternatives for improving watershed water quality. To better apply conservation practices in watersheds and measurably improve agricultural water quality, we should, at least initially, be assessing those practices that can be sited most prevalently across landscapes and watersheds prioritized for water quality improvement efforts. In this paper, we explore how the prevalence of locations suited to conservation practices may differ among agricultural landscape regions. Understanding how each conservation practice fits into different agricultural landscapes may help refine strategies for regional conservation planning and conservation practices research. At the same time, regional evaluations could provide guidance on how user options available within precision conservation technologies, meaning here the practice-placement tools found in the Agricultural Conservation Planning Framework (ACPF), should be applied in different agricultural landscapes.

The ACPF provides a conceptual basis for multipractice conservation planning in agricultural watersheds (Tomer et al. 2013b), supported by high-resolution data available for much of the US Corn Belt (Tomer et al. 2017), and an ArcGIS (Esri 2017) toolbox with tools that can be used for (1) "hydro-enforcing" high-resolution elevation data to resolve overland flow pathways throughout a watershed, (2) delineation of perennial streams for riparian assessment and design of riparian buffers (Tomer et al. 2015a), and (3) identifying potential locations to install a variety of in-field, edge-of-field, and riparian

Mark D. Tomer (corresponding author) is a research soil scientist, USDA Agricultural Research Service (ARS), National Laboratory for Agriculture and the Environment, Ames, lowa. Jessica D. Van Horn (Beasley) is formerly a physical science technician with USDA ARS, currently senior geographic information systems (GIS) analyst, Geographic Technologies Group, Goldsboro, North Carolina. Sarah A. Porter is formerly a physical science technician with USDA ARS, currently senior GIS analyst, Environmental Working Group, Minneapolis, Minnesota. David E. James is a geographic information specialist, USDA ARS, Ames, lowa. Jarad Niemi is an associate professor, lowa State University, Department of Statistics, Ames, lowa. 
conservation practices (Porter et al. 2018). The ACPF Version 3 toolbox was written in the Python (Ver. 2.7) programing language and can be used in ArcGIS software (with an advanced license), Ver. 10.3-10.6, with a separate toolbox written in Python (Ver. 3.5) for use in ArcGIS Pro (Ver. 1-2). The user manual (Porter et al. 2018) is detailed, and the programs are well commented to facilitate review, and if desired, customized editing of the programs by users. The toolbox, user manual, and training resources are available online (www.acpf4watersheds.org). Developed at the National Laboratory for Agriculture and the Environment in Ames, Iowa, of USDA's Agricultural Research Service (ARS), the ACPF has been utilized in research conducted outside USDA to evaluate distributions of existing conservation practices (Rundhaug et al. 2018), to optimize the economics of conservation planning scenarios (Zimmerman et al. 2019), to assess social responses to precision conservation planning tools (Church et al. 2019), and in environmental policy analysis (Konopacky and Ristino 2017). More than 200 watershed plans (many, but not all, in Iowa) have utilized ACPF analyses to identify conservation practice-placement options (Iowa Soybean Association 2019; English River Watershed Management Authority 2019). A key premise of the ACPF is that input data are derived from public sources to provide consistency in approach, but that practice-placement tools are designed to be flexible so that a planner with local knowledge can customize results to the landscape. The ACPF toolbox has been used in local watershed projects in several states and can successfully link farm and watershed planning (Ranjan et al. 2020). We hypothesize here that cross-watershed analyses of ACPF results can also inform regional planning efforts.

Precision conservation that is based on high-resolution data could inform regional conservation planning, particularly if these data can show how conservation practice-placement opportunities differ among landscape regions. Several approaches to characterize and map US landform regions have been proposed. Ecoregions (Olmernik 1987; Olmernik and Griffith 2014), developed for the US Environmental Protection Agency (USEPA), have been among the most commonly used. Ecoregions were first intended to provide a spatial framework for managing aquatic ecosystems in the United States. The utility of the ecoregion framework has evolved to include terrestrial systems, partly driven by a need to find harmony among regional mapping products across US federal agencies (McMahon et al. 2001; Olmernik and Griffith 2014; Salley et al.2016). Patterns and dynamics of land cover has, accordingly, been segregated by ecoregion (Gallant et al. 2004). Under the USDA, the Natural Resources Conservation Service (NRCS) developed Major Land Resource Areas (MLRA; see USDA NRCS 2006), which are contiguous areas of similar physiography, geology, climate, and hydrology, and that share common soil associations and soil resource concerns. The first delineations of MLRAs were published in the 1930s and were aimed to identify areas with similar priorities for soil erosion management and research (Norton 1937). We utilized MLRAs for this research, given their historical tie to soil resource management, and selected three of Iowa's largest MLRAs-103,104, and 108C (figure 1) - for study. These MLRAs are equivalent to USEPA level four ecoregions. Following is a brief description of each MLRA, with the corresponding USEPA ecoregion listed as well. Further detail on each MLRA is available (USDA NRCS 2006).

\section{Figure 1}

Map figure showing Major Land Resource Areas (MLRA) in lowa, and Agro-Hydrologic Landscape designations of HUC 12 watersheds. The 32 watersheds selected for this study are also indicated.

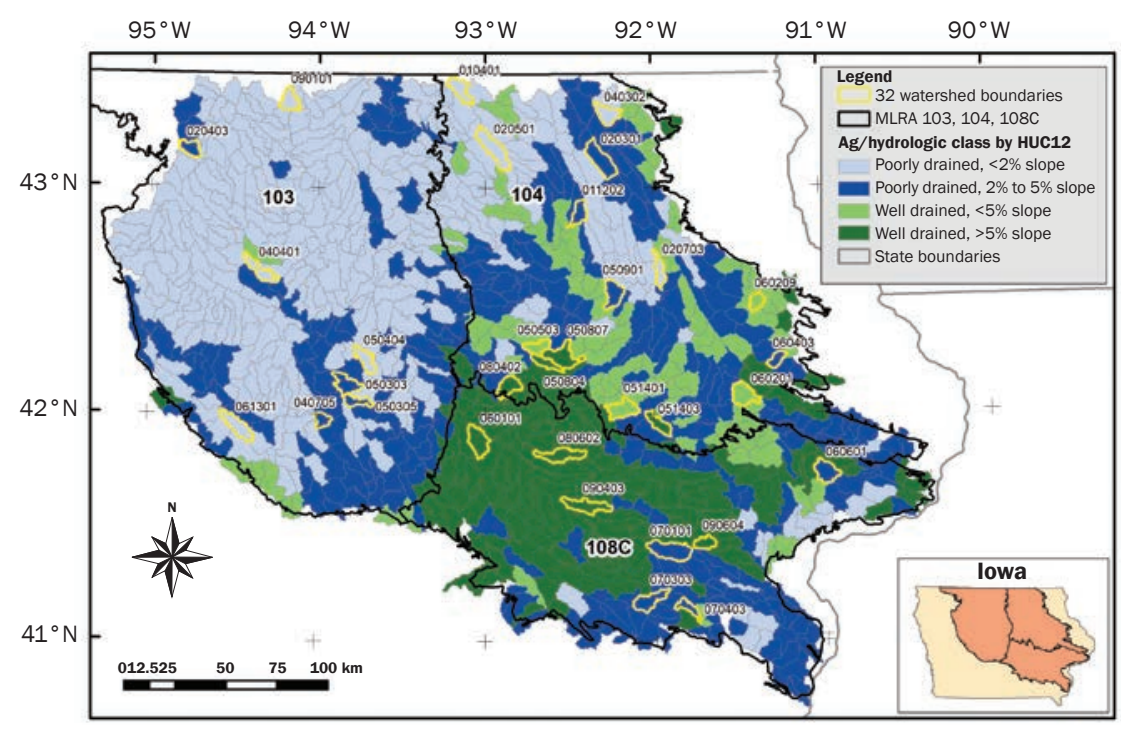

MLRA 103, Central Iowa and Minnesota Till Prairies (ecoregion 47b, Des Moines Lobe), is an area dominated by recent ( 10,000-year-old) Wisconsinan glaciation. The landscape ranges from level to gently rolling, with closed depressions (prairie potholes) being common. Areas with the greatest relief are associated with moraines and the flanks of river valleys. About $75 \%$ of the region's land cover is annual crops, dominantly corn (Zea mays L.) and soybean (Glycine max L.) production. Average annual precipitation varies from 625 to $850 \mathrm{~mm}$. Soils are typically classed (Great Group level) as Hapludolls (e.g., Clarion and Nicollet series) and Haplaquolls (e.g., Webster and Canisteo series).

MLRA 104, Eastern Iowa and Minnesota Till Prairies (ecoregion 47c, Iowa Surface), is a region covered by Illinoian-aged tills $(>50,000$ years), with near-level to gently rolling terrain. The area was in a peri-glacial environment during the Wisconsinan glacial advance, and as a result the landscape has been little-dissected by streams. Average annual precipitation is 700 to $850 \mathrm{~mm}$. Hapludolls (e.g., Kenyon and Floyd series), Argiudolls (e.g., Dinsdale series), and Haplaquolls (e.g., Clyde and Marshan series) are dominant soil types.

MLRA $108 \mathrm{C}$ is the Illinois and Iowa Deep Loess and Drift, West Central Part 
(overlaps with ecoregion 47f, Rolling Loess Prairies). This area of southern Iowa is dominated by older pre-Illinoian ( $~ 500,000$ years) glacial till that is well dissected by streams. The landscape became mantled with loess during Wisconsinan glacial recession. Average annual precipitation ranges from 840 to 965 $\mathrm{mm}$. A wider mix of Alfisols and Mollisols are co-dominant relative to MLRAs 103 and 104 because of the older, more incised terrain and mix of original vegetation. Land cover is also more mixed with pasture grasses covering steeper areas of the landscape; cropland is less extensive than in MLRAs 103 and 104.

In this study, we also explored the utility of a second landscape classification scheme for defining conservation strategies and the potential extents of specific practices. Schilling et al. (2015) developed an approach to derive Agro-Hydrologic Landscapes (AHLs) to help planners assign suites of conservation practices to different types of landscapes dominated by agricultural production (McLellan et al. 2018). Individual hydrological unit code (HUC)12 watersheds are classed based on slope steepness and soil drainage classes of dominant soil map units. These attributes are hypothesized to affect the relative dominance of surface runoff and subsurface flow pathways. Each conservation practice meant to control water flows and provide water quality benefits is designed to intercept a given flow pathway (Tomer et al. 2013b). Therefore, if we can estimate relative dominance of different flow paths, we may be able to predict the types of practices most appropriate, in terms of having relatively larger numbers of suitable placement opportunities, for a watershed. A summary of AHLs is presented (table 1, based on Schilling et al. [2015]), as are spatial distributions of AHLs among Iowa HUC12 watersheds within MLRAs 103, 104, and 108c (figure 1). A key difference in the derivation of MLRAs and AHLs is that spatial information on climate, geology and geomorphology, and land use was divided into regions in developing MLRAs, while information on soil map units was aggregated in assigning HUC12 watersheds to an AHL.

There are examples in the literature where water quality data collected across broad areas were assessed to determine how well landscape regions captured variability of the data. Robertson and Saad (2003) identified land use and soil characteristics that helped differentiate relative rates of nutri-

\section{Table 1}

Agro-Hydrologic Landscape (AHL) classes formed by combining two generalized soil drainage classes (PD: poorly drained; WD: well drained) and two slope classes ( $(2 \%, 2 \%$ to $5 \%$ for poorly drained, $\langle 5 \%$ and $>5 \%$ for well drained) that convey dominant soil map units across a watershed (adopted from Schilling et al. [2015]).

\begin{tabular}{llll}
\hline Slope & Poorly drained soil & & Well drained soil \\
\hline Slopes $>5 \%$ & PD $>5$ (rare in lowa) & & WD $>5$ \\
Slopes $<5 \%$ & PD $<2$ (not dissected & PD2-5 (dissected & WD $<5$ \\
& $[<2 \%])$ & {$[2 \%$ to 5\%]) }
\end{tabular}

ent losses within USEPA ecoregions. Simon and Klimetz (2008) characterized sediment loading curves within USEPA ecoregions to determine if water quality records collected for Conservation Effects Assessment Project watersheds were representative of their ecoregion. Streamflow data have also been considered in regionalization research because of the cost/expense of establishing new streamflow monitoring efforts and the duration of monitoring required for statistical characterization. One of the more noteworthy efforts was the development of Hydrologic Landscape Regions (HLRs; Wolock et al. 2004), which was based on a principle components analysis of soil, geologic, slope, and climate data to distribute watersheds among 20 HLRs.

The specific objectives of this paper are to (1) characterize by-field slope and landuse statistics and describe conservation practice-placement opportunities identified utilizing the ACPF toolbox among 32 Iowa watersheds, and (2) assess the feasibility of using MLRAs and AHLs to describe variation of ACPF results, and thereby the potential for ACPF practice placement results to inform regional conservation planning. We included these two landscape classification systems because of the important distinction between them: MLRAs were developed by delineations (separation) based on climate, geology, topography, and land use, whereas watersheds are assigned to an AHL class based on aggregation (grouping) of soil map unit data. We hypothesized that the MLRAs and AHLs exhibit unique suites of opportunities for conservation practice placements, due to similarities of soils, agricultural hydrology (extent of artificial drainage), and landscape slope configurations within these differing soil-based approaches to landscape classification.

\section{Materials and Methods}

Selection of Watersheds. Watersheds were randomly selected to represent four headwater watersheds from at least two AHLs in MLRAs 103, 104, and 108C. The AHLs selected were PD2-5 and PD $<2$ for MLRA 103; PD2-5, PD < 2, WD $>5$, and WD $<$ 5 for MLRA 104; and PD2-5 and WD > 5 for MLRA 108C; resulting in selection of 32 HUC12 watersheds (figure 1). Note that a given MLRA is unlikely to contain watersheds representing all five AHLs.

Watershed Data Processing. The ACPF databases including field boundaries, land use, and soils (Tomer et al.2017) were obtained for each of these 32 watersheds, along with high resolution digital elevation models (DEMs; 2 $\mathrm{m}$ grid) derived from a light detection and ranging (LiDAR) survey of Iowa (University of Northern Iowa 2016). The ACPF landuse database includes information on crop rotation based on six years (2011 to 2016) of land cover for each field in the watershed. Agricultural land use is also segregated between annual (row) crops and perennial cover (pasture/hay classes) within ACPF watershed databases (Tomer et al. 2017).

The DEMs were hydro-conditioned using DEM editing tools in the ACPF V 3 toolbox (Porter et al. 2018). These DEM-editing tools are designed to digitally "cut" artificial impoundments caused by bridges and roads to allow pathways and accumulation of overland flows to be accurately represented through terrain processing. The process of hydro-conditioning a watershed DEM using the ACPF tools is previously described (Tomer et al. 2013a; Porter et al. 2018). Cuts representing likely culvert locations were made along flow paths with a minimum of 2 ha contributing area. The extents of perennial streams were determined by manual interpretation of aerial imagery. Drainage density was calculated for each watershed (area divided by summed lengths of perennial streams). The watershed area was determined by delineating a new watershed boundary based on the $2 \mathrm{~m}$ DEM.

The by-field slope statistics tool in the ACPF toolbox (Porter et al.2018) was used to identify the 75 th percentile slopes for every field. The 75 th percentile slope is used in the 
ACPF to rank runoff risk among fields; this slope statistic defines the steepest quarter of each field and is consistent with a phosphorus $(\mathrm{P})$ index approach to assessing relative erosion risk among fields (Lewandowski et al. 2006; Porter et al. 2018). The median by-field 75 th percentile slope values were determined for each watershed.

Tile Drainage and Controlled Drainage. Fields potentially suited for controlled drainage (CD) (Williams et al. 2015) were identified among annually cropped fields deemed to be tile drained. Because the actual extent of tile drainage is not public information (Tomer et al. 2015b), the ACPF user selects from among four queries to estimate the extent of artificial subsurface (tile) drainage in a watershed. All four queries are based on two criteria; the first criteria, in all four queries, specifies that slopes must be under $5 \%$ on over $90 \%$ of the field. The second criteria is based on soil survey information and has two options to designate the field as tile drained: either hydric soils must cover over $10 \%$ of the field, or soils of a dual hydrologic group (e.g., B/D) must cover over $40 \%$ of the field. A dual hydrologic group indicates a soil map unit that must be artificially drained to support crop production. The user chooses one of the two soils criteria, and then selects whether both the slope and soil criteria must be met (AND operator, which narrows the selection), or if meeting either criteria designates the field as tile drained (OR operator, which widens the selection). This flexibility is intended to enable users to better match results to local knowledge about the extent of tile drainage (see Tomer et al. [2015b] for discussion). The ACPF tile drainage tool applies the selected query to all agricultural fields, including crop and pasture/hay land cover types. For this study, we ran all four queries and recorded the maximum and minimum results (proportion of fields esti- mated to be tile drained), which provided a measure of the uncertainty of the extent of tile drainage among the watersheds.

The potential extent of CD was assessed assuming the maximum extent of tile drainage found among the four queries. The CD tool allows the user to specify an elevation contour interval between 0.3 and $1.5 \mathrm{~m}$ and choose the proportion of a field $(30 \%$ to $90 \%$ range) the selected contour interval must occupy for the field to be considered a candidate for CD implementation (Porter et al. 2018). We ran the tool twice to identify fields in which 0.5 and $1.0 \mathrm{~m}$ contour intervals occupied at least $30 \%$ of the field. A single water table control gate can control the water table within about a $0.5 \mathrm{~m}$ elevation range; therefore, these two runs identified fields where the CD practice could provide water table management of over $30 \%$ of the field with one or two control gates (Tomer et al. 2015b). These criteria may overestimate the actual extent of CD candidates from a practical standpoint, but planners are encouraged to prioritize CD implementation in areas where fields suited to the CD practice are clustered.

Runoff Control Practices. After identifying areas potentially suited to $\mathrm{CD}$, additional conservation practice siting tools in the ACPF toolbox were used to map candidate locations for installation of contour buffer strips (CBS) (Zhou et al. 2014), water and sediment control basins (WASCOBs) (Mielke 1985), and grassed waterways (GWWs) (Fiener and Auerswald 2003). Criteria utilized for these practice-placement tools that can be modified by the user are given in table 2 , and further information on practice siting criteria are given in Porter et al. (2018).

Candidate locations for GWWs, by default selection, had Stream Power Index (SPI) values more than 3.5 standard deviations greater than the watershed mean SPI, therefore SPI thresholds were also compared among the watersheds. Note SPI = $\log [\mathrm{CuS}]$, with $\mathrm{Cu}$ denoting specific contributing area and $\mathrm{S}$ denoting slope tangent. This differed from criteria used for GWW siting in early versions of the ACPF (Tomer et al. 2015b). Published studies on the use of the SPI and high-resolution DEMs to locate flow pathways subject to gully erosion, where GWW installation would be appropriate, have included field-scale evaluations of one or a small number of fields (Galzki et al. 2011; Pike et al. 2009). To our knowledge, only one watershed-scale assessment of GWW placement has been conducted, with terrain derivatives other than SPI (i.e., curvature and topographic wetness index) used to suggest GWW locations (Gali et al. 2015). Therefore, one purpose here is to use this cross-watershed analysis to develop guidance for applying the ACPF's SPI-based GWW siting tool in watershed planning. The SPI values were determined using TauDEM 5.3 (Utah State University 2015), using a filled DEM and D-infinity flow routing, which maps areas of dispersive overland flow (Tarboton 1997). The functionality of mapping dispersion/spreading of flows over the surface enables suggested placements of GWWs that terminate below footslope positions where slopes diminish. This reflects actual GWW placements; for example, GWWs are seldom continued from footslopes across alluvial floodplains. The option to exclude GWWs where they cross topographic depressions was also selected in the ACPF user interface (Porter et al. 2018). Most depressions occurred in MLRA 103 and watersheds with a PD $<2$ AHL designation in MLRA 104 (not shown).

Statistical Analysis. To begin, basic watershed attributes of drainage density, proportion of watershed under annual cropping, and perennial agricultural cover (pasture/hay)

\section{Table 2}

Summary of practice opportunities mapped among 24 watersheds and user-defined threshold criteria applied to suggest placement opportunities for each practice using the Agricultural Conservation Planning Framework (ACPF) toolbox (Porter et al. 2018).

\begin{tabular}{lll}
\hline Conservation practice & Criteria & Applied to \\
\hline Controlled drainage (CD) & $\begin{array}{l}\text { 0.5 m and/or } 1 \mathrm{~m} \text { contour interval occupies }>30 \% \text { of field } \\
\text { Default spacing between strips (slope dependent); minimum } 8 \text { contiguous } \\
\text { hectares in a field with }>4 \% \text { slopes }\end{array}$ & $\begin{array}{l}\text { Annually cropped tile drained fields } \\
\text { Annually cropped fields }\end{array}$ \\
$\begin{array}{ll}\text { Water and sediment control } \\
\text { basins (WASCOBs) }\end{array}$ & $\begin{array}{l}1 \mathrm{~m} \text { impoundment of }<200 \mathrm{~m} \text { length can detain water along flow paths } \\
\text { carrying runoff from } 0.8 \text { to } 20 \text { ha }\end{array}$ & Annually cropped fields and pasture \\
Grassed waterways (GWWs) & Stream power index of $>3.5 \mathrm{SDs}$ (range 2 to $5 \mathrm{SDs}$ ) above watershed mean & Annually cropped fields
\end{tabular}


were characterized. Effects of drainage density on land-use distributions and (median) field size were explored using linear regression.

Potential rates of practice implementation were tallied for each practice based on their density or rate of occurrence. That is, in all 32 watersheds, ACPF results were tallied to count the number of suggested practice placements per $100 \mathrm{ha}\left(1 \mathrm{~km}^{2}\right)$ of cropland for CBS, per 100 ha of agricultural land (cropland plus pasture/hay) for WASCOBs, and as a fraction of tile-drained agricultural land (portion of cropland plus pasture/hay) for CD. Practices and field areas were tallied among fields for which the geographic centroid was within the watershed boundary. The practice-placement frequencies were log-transformed and then statistically tested to identify differences among landform regions using analysis of variance followed by a set of contrasts (table 3). First, a single-factor analysis of variance (ANOVA) was applied to determine if combined MLRA-AHL classes, with four watersheds in each of eight combined classes, had a significant effect on the by-watershed, practice-frequency results. If the overall ANOVA result was significant $(p$ $<0.05$ ), then a set of 17 comparison contrasts were run to determine whether differences occurred among MLRA classes, AHL classes, or if differences among both landscape classes were responsible for the significant ANOVA result. Conducting these analyses on log-transformed data means that the contrast value, upon exponentiation, is interpreted as a multiplicative (rather than additive) effect, with its significance determined by whether its $95 \%$ confidence interval excluded a value of 1.0. Where significant, the ratio indicates multiplicative/fractional differences in by-field practice-placement frequencies between landscape classes/groupings as contrasted. These statistical tests were run using SASV 9.2, Proc. GLM. The comparison contrasts are listed in table 3 and illustrated in figure 2 , providing a reference/template to identify significant differences among the results. Watershed characteristics (drainage density, mean by-field 75 th percentile slope) were also subjected to the same ANOVA/ comparison contrast analyses.

A slightly different approach was used for the GWW practice because the SPI-based threshold used for siting GWWs is watershed specific. The above described statistical analyses were applied to the by-watershed mean SPI values and their standard deviations. The

\section{Table 3}

Listing of comparison contrasts that were run among Major Land Resource Areas (MLRAs) and Agro-Hydrologic Landscape (AHL) classes. Figure 2 provides an illustration of the contrasts among MLRA-AHL groupings. The contrast IDs are used to graphically illustrate significant differences in subsequent figures.

\begin{tabular}{|c|c|c|}
\hline Contrast ID & Contrast type & Contrast \\
\hline 1 & MLRA (among multiple AHLs) & 103 to 104 (PD < 2 and PD2-5) \\
\hline 2 & & 104 to $108 C(P D 2-5$ and WD > 5) \\
\hline 3 & AHL (among multiple MLRAs) & PD $<2$ to PD2-5 (103 and 104) \\
\hline 4 & & PD2-5 to WD > 5 (104 and 108C) \\
\hline 5 & MLRA (within one AHL) & 103 to $104(\mathrm{PD}<2)$ \\
\hline 6 & & 103 to 104 (PD2-5) \\
\hline 7 & & 103 to $108 \mathrm{C}$ (PD2-5) \\
\hline 8 & & 104 to $108 \mathrm{C}(\mathrm{PD} 2-5)$ \\
\hline 9 & & 104 to $108 \mathrm{C}(\mathrm{WD}>5)$ \\
\hline 10 & AHL (within one MLRA) & PD $<2$ to PD2-5 (103) \\
\hline 11 & & PD $<2$ to PD2-5 (104) \\
\hline 12 & & $\mathrm{PD}<2$ to $\mathrm{WD}<5(104)$ \\
\hline 13 & & $\mathrm{PD}<2$ to $\mathrm{WD}>5(104)$ \\
\hline 14 & & PD2-5 to WD < 5 (104) \\
\hline 15 & & PD2-5 to WD > 5 (104) \\
\hline 16 & & WD < 5 to WD > 5 (104) \\
\hline 17 & & PD2-5 to WD > 5 (108C) \\
\hline
\end{tabular}

SPI mean and standard deviation is determined from whole-watershed data, but then applied only to that portion of the watershed in row crop production. We determined the fraction of cropland (total area) in each watershed with SPI values exceeding 2, 3.5, and 5 standard deviations above the watershed mean. These exceedance percentages were evaluated to identify differences among landscape groupings using the ANOVA and comparison contrasts described above, again using log transformation. We then ran the GWW tool for all three thresholds and evaluated how the length-density of GWWs $(\mathrm{km}$ of GWW km${ }^{-2}$ of cropland in the watershed) was related to the SPI exceedance values. The result enables us to provide advice on the use of the ACPF GWW placement tool where the user can identify a target GWW density for cropland in a watershed.

\section{Results and Discussion}

Watershed Characteristics: Land Use, By-Field Slopes, and Drainage Density. The 32 watersheds varied in size and land use, with 2,684 to 13,029 ha of cropland and between 50 and 1,891 ha of pasture/hay (table 4). The counts of agricultural fields varied from 112 to 434 cropped fields, plus 3 to 100 fields under perennial cover (pasture/ hay). Drainage density ranged from 0.24 to $1.46 \mathrm{~km}$ stream length $\mathrm{km}^{-2}$ of watershed (table 4), with significant differences among landscape groupings found by several comparison contrasts (table 5). Watersheds in MLRA 108C had significantly greater drainage densities than MLRAs 103 and 104 ( $p$ $<0.05)$ when keeping AHL class consistent (contrasts 2 and 7, table 5), while watersheds in MLRA 103 had lower drainage densities than those in MLRA 104 (contrasts 1 and 5 , table 5). Watersheds in the PD $<2$ AHL also had lower drainage densities than those in the PD2-5 AHL when MLRA classes were kept consistent (Contrasts 3 and 10, table 5). Agricultural land use is influenced by the landscape, and we found, by regression analyses, that watersheds with smaller drainage densities were associated with increased extents of crop production $\left(R^{2}=0.73\right)$, decreased extents of agricultural land in pasture/hay cover classes $\left(R^{2}=0.67\right)$, and larger cropped fields among these Iowa watersheds $\left(R^{2}=0.49\right)$ (figure 3). This suggests that the most extensively cropped watersheds have the least extensive options to mitigate agricultural impacts on water quality using riparian buffers.

Median by-field 75th percentile slopes were found for each watershed (table 4) and compared among landscape groupings. Contrasts among AHLs with differing slope classes, as expected, showed significant differences (Contrasts 3, 4, 11 to 13, 15, and 17; table 5). However, there were also slope differences among MLRAs when AHL slope 


\section{Figure 2}

Key to identify the 17 statistical comparison contrasts run among Major Land Resource Areas (MLRA) and Agro-Hydrologic Landscape (AHL) groupings, as listed in table 3.

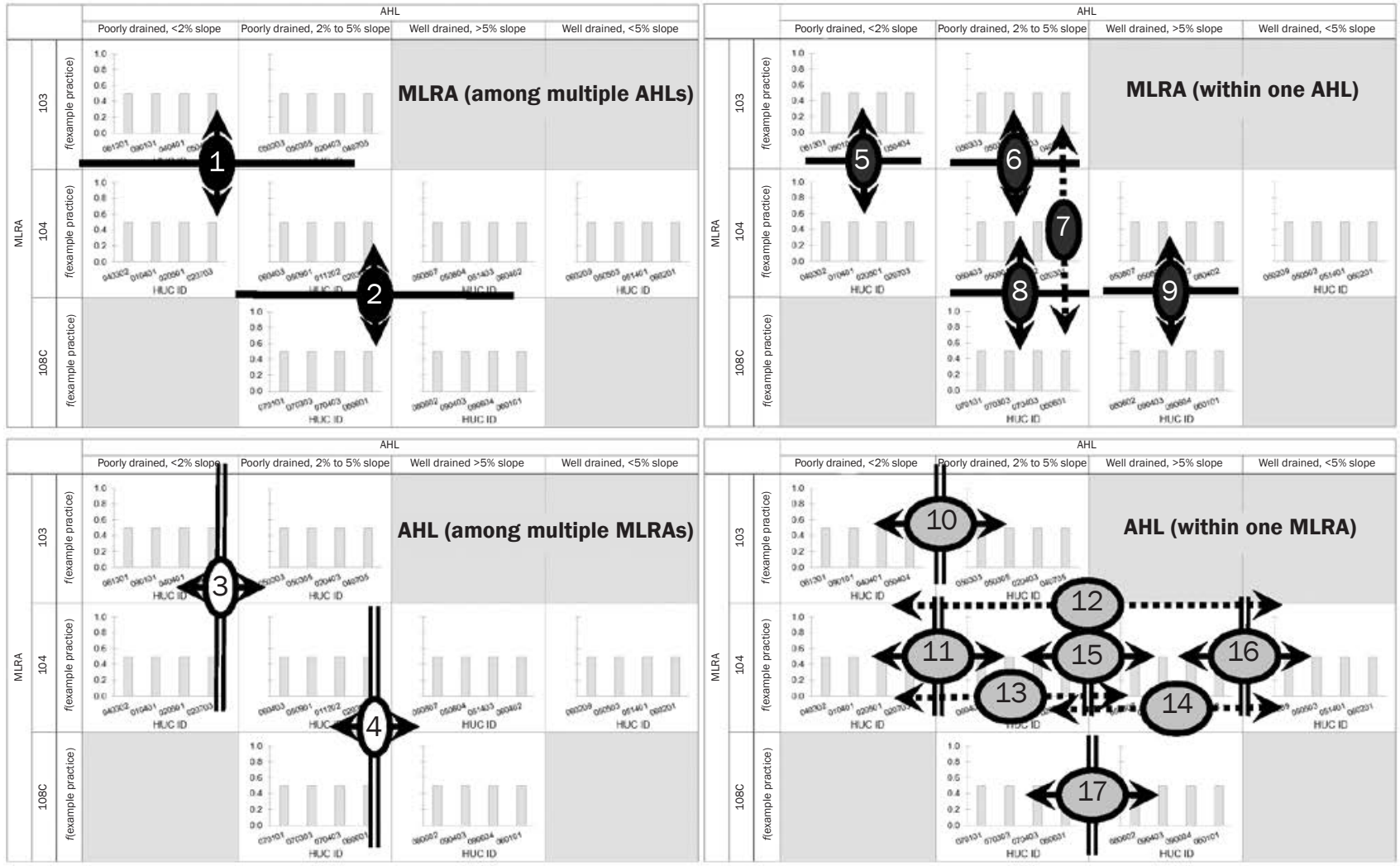

\section{Figure 3}

Influence of drainage density on agricultural land use in lowa headwater watersheds. The proportion of cropland and average field size decrease with increasing drainage density, while the proportion of pastureland increases.

(a)

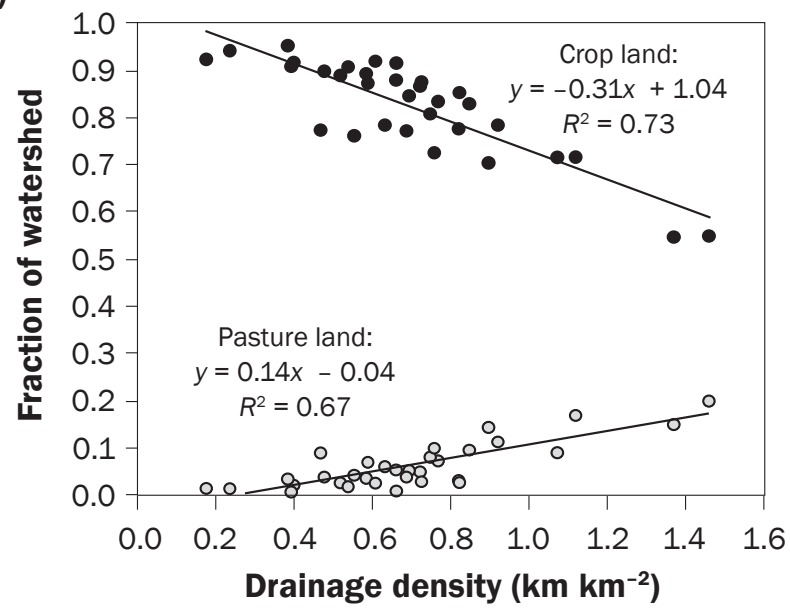

(b)

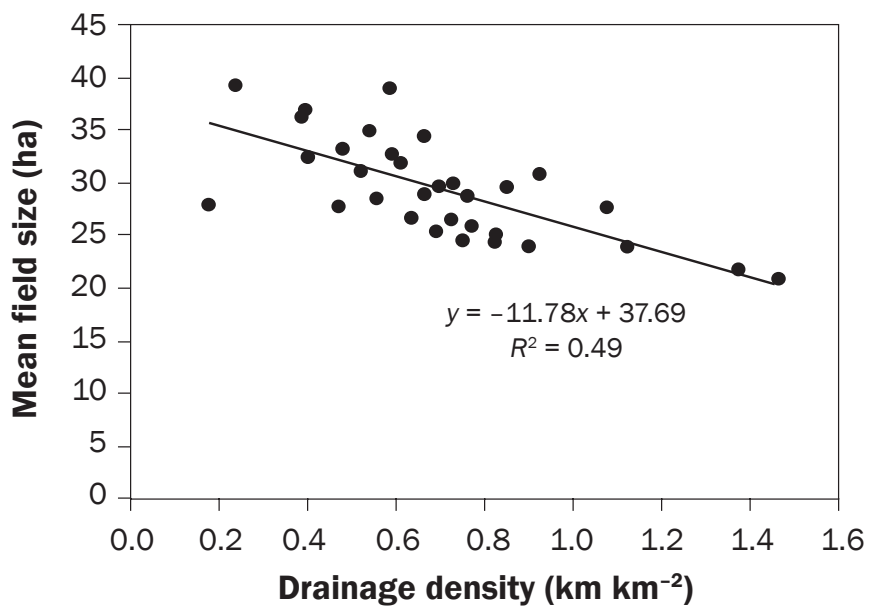

classes were kept consistent (Contrasts 2 and 7 to 9 ; table 5), suggesting the AHL designation does not completely account for by-field slope variations found among MLRAs.
Extent of Tile Drainage and Controlled Drainage Opportunities. The extent of tile drainage was estimated by four queries including slope and/or soil criteria. Maximum estimated extents of tile drainage exceeded $50 \%$ of cropped fields, on average, among all eight combined MLRA-AHL groupings, but equaled or exceeded $89 \%$ of agricultural 
Table 4

Summary data for 32 watersheds including area, drainage density, land use, field counts, and 75th percentile slopes, and ranges in tile drainage extents estimated by four queries.

\begin{tabular}{|c|c|c|c|c|c|c|c|c|}
\hline \multirow[b]{2}{*}{ Watershed ID } & \multirow[b]{2}{*}{ MLRA/AHL } & \multirow[b]{2}{*}{ Area (ha) } & \multirow{2}{*}{$\begin{array}{l}\text { Drainage } \\
\text { density } \\
\left(\mathbf{k m ~ k m}^{-2}\right)\end{array}$} & \multirow{2}{*}{$\begin{array}{l}\text { Cropped fields/ } \\
\text { pastures }(n)\end{array}$} & \multirow{2}{*}{$\begin{array}{l}\text { Area cropland/ } \\
\text { pasture (ha) }\end{array}$} & \multirow{2}{*}{$\begin{array}{l}\text { Median 75th } \\
\text { percentile } \\
\text { slope of cropped } \\
\text { fields/pastures (\%) }\end{array}$} & \multicolumn{2}{|c|}{$\begin{array}{l}\text { Fields that are tile } \\
\text { drained (\%): range } \\
\text { estimated by four queries }\end{array}$} \\
\hline & & & & & & & Max. & Min. \\
\hline 50303 & 103/PD2-5 & 8,759 & 0.77 & $282 / 48$ & $7,317 / 615$ & $3.8 / 13.3$ & 96 & 37 \\
\hline 50305 & & 5,153 & 0.82 & $164 / 10$ & $4,006 / 158$ & $3.6 / 5.6$ & 99 & 49 \\
\hline 20403 & & 5,928 & 0.47 & $165 / 25$ & $4,591 / 529$ & $4.0 / 6.8$ & 97 & 28 \\
\hline 90101 & $103 / \mathrm{PD}<2$ & 7,216 & 0.24 & $173 / 3$ & $6,806 / 100$ & $3.0 / 3.3$ & 100 & 68 \\
\hline 40401 & & 8,424 & 0.40 & $238 / 11$ & $7,739 / 173$ & $2.3 / 11.8$ & 99 & 70 \\
\hline 61301 & & 14,852 & 0.39 & $274 / 20$ & $9,949 / 351$ & $3.1 / 9.8$ & 99 & 64 \\
\hline 50404 & & 7,328 & 0.18 & $242 / 8$ & $6,777 / 105$ & $3.1 / 2.8$ & 99 & 64 \\
\hline 60403 & 104/PD2-5 & 4,333 & 1.07 & $112 / 18$ & $3,106 / 390$ & $4.8 / 11.9$ & 67 & 18 \\
\hline 10401 & & 7,896 & 0.39 & $194 / 4$ & $7,183 / 50$ & $1.4 / 1.9$ & 100 & 95 \\
\hline 20501 & & 13,757 & 0.52 & $393 / 23$ & $12,254 / 356$ & $1.0 / 5.7$ & 100 & 82 \\
\hline 20703 & & 6,167 & 0.75 & $203 / 32$ & 4,991/496 & $3.2 / 4.9$ & 95 & 51 \\
\hline 50804 & 104/WD > 5 & 5,515 & 0.59 & $147 / 15$ & $4,824 / 382$ & $6.8 / 15.4$ & 71 & 11 \\
\hline 51403 & & 6,717 & 0.82 & $228 / 12$ & $5,740 / 175$ & $5.3 / 6.3$ & 93 & 4 \\
\hline 80402 & & 8,341 & 0.66 & $213 / 28$ & $7,346 / 444$ & $6.3 / 9.0$ & 47 & 9 \\
\hline 50807 & & 13,037 & 0.48 & $352 / 20$ & $11,725 / 500$ & $5.6 / 13.5$ & 70 & 13 \\
\hline 60209 & 104/WD < 5 & 4,840 & 0.76 & $122 / 25$ & $3,517 / 481$ & $4.4 / 7.8$ & 61 & 14 \\
\hline 50503 & & 6,475 & 0.54 & $168 / 7$ & $5,884 / 113$ & $5.9 / 6.6$ & 83 & 6 \\
\hline 51401 & & 10,240 & 0.66 & $324 / 6$ & $9,392 / 92$ & $3.7 / 8.4$ & 96 & 37 \\
\hline 90604 & & 5,185 & 0.90 & $152 / 49$ & $3,655 / 744$ & $8.6 / 10.7$ & 57 & 4 \\
\hline 60101 & & 10,824 & 0.85 & $303 / 51$ & 8,991/1,030 & $9.1 / 13.9$ & 38 & 1 \\
\hline
\end{tabular}

fields for all poorly drained AHLs (table 6). The variation among the four queries was least for PD $<2$ AHL watersheds, where extensive tile drainage would be expected, and was greatest for AHLs dominated by well drained soils, where tile drainage is less common (table 6). Generally, and as expected, the least extents of tile drainage were found in MLRA $108 \mathrm{C}$ and in watersheds with well drained AHL classes.

Opportunities to install CD were counted where at least $30 \%$ of a tile-drained field's area was within either a 1.0 or a $0.5 \mathrm{~m}$ contour interval. Although the extent of tile drainage tends to be least in MLRA 108C, tile-drained fields contributed more frequently to the tallies of areas suited to CD in MLRA $108 \mathrm{C}$ than those in MLRA 104 (table 5; Contrasts 2 and 8). Within MLRA 104 , tile drained fields within $\mathrm{PD}<2$ AHL watersheds could more frequently be fitted with drainage control gates than drained fields in watersheds with steeper or better drained AHL designations (table 5; contrasts 11 to 12). There was evidence that within the PD2-5 AHL, opportunities for CD in MLRA 103 were more common than in MLRA 104, but only for the larger (1 m) contour interval (Contrast 6; table 5), suggesting implementation of CD systems in
PD2-5 AHL watersheds may require more sophisticated engineering design in MLRA 103. This result is consistent with the younger terrain of MLRA 103, which has a more undulating (gently rolling) topography across short-range (within-field) distances, which this landform region inherited from depositional patterns associated with recent glacial ice fracture and melt.

Runoff Control Practices: Contour Buffer Strips and Water and Sediment Control Basins. Suggested placement of CBS by the ACPF were sparse: $<2.5 \mathrm{~km}^{-2}$ in all $\mathrm{PD}<2$ AHL watersheds, but greater than $2.5 \mathrm{~km}^{-2}$ among all other watersheds, excepting one 
Table 5

Summary of comparison contrasts found to be significant, with significance levels and $95 \%$ confidence intervals. Numbers indicate proportional/ multiplicative differences in values (drainage density and slope) or in densities of controlled drainage (CD) and runoff control practices among Major Land Resource Area (MLRA)/Agro-Hydrologic Landscape (AHL) groupings listed.

\begin{tabular}{|c|c|c|c|c|c|c|c|}
\hline \multicolumn{2}{|l|}{ Contrast } & \multicolumn{2}{|c|}{ Characterization } & \multicolumn{2}{|l|}{ Tile drainage } & \multicolumn{2}{|l|}{ Runoff practices } \\
\hline Contract name (pooling) & $\begin{array}{l}\text { Contrast } \\
\text { no. }\end{array}$ & $\begin{array}{l}\text { Drainage } \\
\text { density }\end{array}$ & $\begin{array}{l}\text { Median 75th } \\
\text { percentile slope }\end{array}$ & $\begin{array}{l}\text { CD-1 m } \\
\text { contour }\end{array}$ & $\begin{array}{l}\text { CD-0.5 m } \\
\text { contour }\end{array}$ & CBS & WASCOBs \\
\hline \multicolumn{8}{|l|}{ MLRAs (multiple AHLs) } \\
\hline $103 / 104$ (PD < 2 and PD2-5) & 1 & $\begin{array}{l}0.65 * * \\
(0.49 \text { to } 0.87)\end{array}$ & & & & & \\
\hline $104 / 108 C(P D 2-5$ and WD $>5$ ) & 2 & $\begin{array}{l}0.73 * \\
(0.54 \text { to } 0.98)\end{array}$ & $\begin{array}{l}0.69 * * * \\
(0.56 \text { to } 0.85)\end{array}$ & $\begin{array}{l}0.34 * * \\
(0.17 \text { to } 0.66)\end{array}$ & $\begin{array}{l}0.14 * * \\
(0.05 \text { to } 0.43)\end{array}$ & & \\
\hline \multicolumn{8}{|l|}{ AHLs (multiple MLRAs) } \\
\hline $\mathrm{PD}<2 / \mathrm{PD} 2-5$ (103 and 104) & 3 & $\begin{array}{l}0.56 * * * \\
(0.42 \text { to } 0.75)\end{array}$ & $\begin{array}{l}0.67 * * * \\
(0.54 \text { to } 0.82)\end{array}$ & & & $\begin{array}{l}0.09 * * * \\
(0.03 \text { to } 0.29)\end{array}$ & $\begin{array}{l}0.14 * * * \\
(0.06 \text { to } 0.33)\end{array}$ \\
\hline PD2-5/WD > 5 (104 and 108C) & 4 & & $\begin{array}{l}0.65 * * * \\
(0.53 \text { to } 0.80)\end{array}$ & & & & \\
\hline \multicolumn{8}{|l|}{ MLRA (within single AHL) } \\
\hline $103 / 104(P D<2)$ & 5 & $\begin{array}{l}0.52 * * \\
(0.34 \text { to } 0.78)\end{array}$ & & & & $\begin{array}{l}21.1 * * * \\
(3.95 \text { to } 112.8)\end{array}$ & $\begin{array}{l}7.50 * * \\
(2.24 \text { to } 25.1)\end{array}$ \\
\hline 103/104 (PD2-5) & 6 & & & $\begin{array}{l}3.41^{*} \\
(1.31 \text { to } 8.89)\end{array}$ & & & \\
\hline 103/108C (PD2-5) & 7 & $\begin{array}{l}0.66 * \\
(0.44 \text { to } 0.99)\end{array}$ & $\begin{array}{l}0.61 * * \\
(0.46 \text { to } 0.81)\end{array}$ & & $\begin{array}{l}0.20 * \\
(0.04 \text { to } 0.95)\end{array}$ & $\begin{array}{l}0.18 * \\
(0.03 \text { to } 0.96)\end{array}$ & $\begin{array}{l}0.12 * * \\
(0.03 \text { to } 0.39)\end{array}$ \\
\hline 104/108C (PD2-5) & 8 & & $\begin{array}{l}0.74 * \\
(0.55 \text { to } 0.98)\end{array}$ & $\begin{array}{l}0.21 * * \\
(0.08 \text { to } 0.56)\end{array}$ & $\begin{array}{l}0.09 * * \\
(0.02 \text { to } 0.45)\end{array}$ & & \\
\hline $104 / 108 C(W D>5)$ & 9 & & $\begin{array}{l}0.65 * * \\
(0.48 \text { to } 0.86)\end{array}$ & & & & \\
\hline \multicolumn{8}{|l|}{$\overline{\mathrm{AHL}}$ (within single MLRA) } \\
\hline $\mathrm{PD}<2 / \mathrm{PD} 2-5$ (103) & 10 & $\begin{array}{l}0.44 * * * \\
(0.30 \text { to } 0.67)\end{array}$ & & & & & \\
\hline $\mathrm{PD}<2 / \mathrm{PD} 2-5(104)$ & 11 & & $\begin{array}{l}0.53 * * * \\
(0.40 \text { to } 0.71)\end{array}$ & $\begin{array}{l}3.47^{*} \\
(1.33 \text { to } 9.05)\end{array}$ & & $\begin{array}{l}0.01 * * * \\
(0.002 \text { to } 0.06)\end{array}$ & $\begin{array}{l}0.04 * * * \\
(0.01 \text { to } 0.13)\end{array}$ \\
\hline $\mathrm{PD}<2 / \mathrm{WD}<5(104)$ & 12 & & $\begin{array}{l}0.48 * * * \\
(0.36 \text { to } 0.65)\end{array}$ & $\begin{array}{l}5.81 * * * \\
(2.23 \text { to } 15.1)\end{array}$ & $\begin{array}{l}7.14 * \\
\text { (1.48 to } 34.5)\end{array}$ & $\begin{array}{l}0.01 * * * \\
(0.002 \text { to } 0.05)\end{array}$ & $\begin{array}{l}0.02 * * * \\
(0.005 \text { to } 0.06)\end{array}$ \\
\hline $\mathrm{PD}<2 / \mathrm{WD}>5(104)$ & 13 & & $\begin{array}{l}0.37 * * * \\
(0.28 \text { to } 0.49)\end{array}$ & & & $\begin{array}{l}0.004 * * * \\
(0.001 \text { to } 0.02)\end{array}$ & $\begin{array}{l}0.006 * * * \\
(0.002 \text { to } 0.02)\end{array}$ \\
\hline PD2-5/WD < 5 (104) & 14 & & & & & & \\
\hline PD2-5/WD > 5 (104) & 15 & & $\begin{array}{l}0.69 * \\
(0.52 \text { to } 0.93)\end{array}$ & & & & $\begin{array}{l}0.15 * * \\
(0.05 \text { to } 0.51)\end{array}$ \\
\hline WD < 5/WD > 5 (104) & 16 & & & & & & \\
\hline PD2-5/WD > 5 (108C) & 17 & & $\begin{array}{l}0.61 * * \\
(0.45 \text { to } 0.81)\end{array}$ & & & & \\
\hline$R^{2}$ of ANOVA & & 0.69 & 0.86 & 0.59 & 0.49 & 0.75 & 0.84 \\
\hline
\end{tabular}

Notes: $95 \%$ confidence intervals (in parentheses) must exclude 1.0 in order to be significant at $p<0.05$. CBS $=$ contour buffer strips. WASCOBs $=$ water and sediment control basins. $\mathrm{PD}=$ poorly drained. $\mathrm{WD}=$ well drained.

$* p<0.05 ; * * p<0.01 ; * * * p<0.001$.

PD2-5 watershed in MLRA 103 (040705). This difference drove several significant contrasts for rates of CBS placement (contrasts 3 and 11 to 13; table 5 and figure 4). The largest rates of CBS placements, $>17 \mathrm{~km}^{-2}$, occurred among all WD > 5 AHL water- sheds. There were $>10$ CBS placements $\mathrm{km}^{-2}$ among the PD2-5 AHL watersheds in MLRA $108 \mathrm{C}$, which was significantly more than occurred in MLRA 103 watersheds of the same PD2-5 AHL (Contrast 7). This difference reflected the more incised ter- rain of MLRA 108C. Even though all PD $<2$ watersheds had sparse CBS placements, Contrast 5, between MLRA 103 and 104 for the $\mathrm{PD}<2 \mathrm{AHL}$, showed a higher rate of CBS placement in MLRA 103, which again 
reflected the younger and more rolling terrain of MLRA 103.

The densities at which WASCOBs were placed (figure 5) among PD $<2$ watersheds were all $<1.4 \mathrm{~km}^{-2}$, but significantly greater for the PD $<2$ watersheds in MLRA 103 than those in MLRA 104 (Contrast 5; table 5 and figure 5). Therefore, both the CBS and WASCOB results showed differences between MLRA 103 and 104 among the PD $<2$ watersheds. The low siting frequency for WASCOBs in PD $<2$ watersheds led to significant contrasts similar to those found for the CBS practice (Contrasts 3, and 11 to 13; figure 5, table 5). Potential WASCOB locations were identified most frequently $(>4$ $\mathrm{km}^{-2}$ ) in MLRA $108 \mathrm{C}$ and WD $>5$ AHL watersheds, leading to additional significant contrasts (Contrasts 7 and 15; table 5).

Runoff Control Practice: Grassed Waterways. We compared watershed SPI means and standard deviations, but the ANOVA among landscape groupings was not significant $(p>0.05)$. This result seems surprising, but there is a reason for it: the well dissected terrain of MLRA $108 \mathrm{C}$ has relatively steep slopes, but the terrain is more finely divided, causing ephemeral waterways to have smaller contributing areas than found in MLRAs 103 and 104 where landforms are more gently sloping. This tradeoff tends to equalize SPI distributions among watersheds because SPI is based on slope and contrib- uting area. To pursue this further, for each watershed, we calculated the percentage of cropland with SPI values greater than 2, 3.5, and 5 standard deviations above the mean, which covers the range of user options in the ACPF GWW tool. These percentage exceedance results were subjected to the same (prior described) ANOVA and comparison contrasts, for each standard deviation threshold. Results (figure 6) showed small, but statistically significant, differences among MLRAs. Specifically, MLRA 104 had more cropland on a fractional basis that exceeded 2 standard deviations above the mean SPI than did MLRA 103 (Contrasts 1, 5, and 6; figure 6). Also, MLRA 104 had more cropland that exceeded 5 standard deviations above the mean SPI than did MLRA 108C (Contrasts 2, 8, and 9; figure 6). This suggests GWW placements by the ACPF may vary among MLRAs, depending on the SPI threshold selected. However, the key question is how the area percentages of SPI exceedances are related to the density of suggested GWW placements. We ran the ACPF GWW tool across all three SPI values for 24 of the watersheds and found a strong linear relationship with a zero intercept (figure 7). Therefore, SPI exceedance values can predict the density (in $\mathrm{km} \mathrm{GWW} \mathrm{km}^{-2}$ of cropland) of GWW placements with high confidence across a range of watersheds. This enables us to provide the following advice for use of the ACPF GWW tool with $2 \mathrm{~m}$ grid DEMs:

1. Identify the density of GWW placements in a watershed (in $\mathrm{km} \mathrm{km}^{-2}$ ) that is desired. The drainage density of perennial streams in the watershed may provide a good starting density. We noted that the density of GWW placements for 3.5 standard deviations above the SPI mean were around $1 \mathrm{~km} \mathrm{~km}^{-2}$ (see figure 7 inset), which is similar stream densities among these watersheds (table 4).

2. Multiply that drainage density times 0.22. The result is the percentage exceedance value expected to provide that targeted GWW density, given the regression shown in figure 7.

3. Mask out noncropped areas of the watershed and plot the cumulative frequency distribution of SPI values for cropland in the watershed. Along the cumulative frequency curve, identify the SPI value associated with the exceedance frequency determined in step 2 .

4. Enter that SPI value as the threshold in the GWW tool interface (rather than choosing between 2 and 5 standard deviations above the mean SPI), run the GWW tool, and evaluate the result.

\section{Summary and Conclusions}

The options available for placement of conservation practices in watersheds vary with

\section{Table 6}

Proportion of fields in each Major Land Resource Area (MLRA)-Agro-Hydrologic Landscape (AHL) landscape grouping estimated to be (1) tile drained (maximum and minimum among four queries); (2) suggested appropriate for controlled drainage (as a proportion of tile drained fields); and (3) suited to runoff control practices including contour buffer strips, water and sediment control basins (WASCOBs), and grassed waterways. Values are geometric means of four watersheds in each landscape grouping.

\begin{tabular}{|c|c|c|c|c|c|c|c|c|}
\hline \multirow[b]{2}{*}{ Proportion of field } & \multicolumn{8}{|c|}{ MLRA and AHL } \\
\hline & $\mathrm{PD}<2$ & PD2-5 & $\mathrm{PD}<2$ & PD2-5 & WD0-5 & WD $>5$ & PD2-5 & WD $>5$ \\
\hline Proportion tile drained (max) & 0.99 & 0.98 & 0.98 & 0.89 & 0.78 & 0.69 & 0.68 & 0.51 \\
\hline Proportion tile drained (min) & 0.68 & 0.50 & 0.79 & 0.36 & 0.16 & 0.09 & 0.18 & 0.02 \\
\hline \multicolumn{9}{|l|}{$\begin{array}{l}\text { Proportion of tile-drained fields } \\
\text { (max estimate) suited for }\end{array}$} \\
\hline Controlled drainage $(1.0 \mathrm{~m})$ & 0.40 & 0.36 & 0.39 & 0.14 & 0.10 & 0.15 & 0.34 & 0.23 \\
\hline \multicolumn{9}{|l|}{$\begin{array}{l}\text { Proportion of fields suited for } \\
\text { practices that intercept runoff }\end{array}$} \\
\hline Contour buffer strips & 0.17 & 0.21 & 0.03 & 0.47 & 0.45 & 0.74 & 0.59 & 0.88 \\
\hline WASCOBS & 0.07 & 0.10 & 0.01 & 0.16 & 0.31 & 0.57 & 0.51 & 0.57 \\
\hline
\end{tabular}




\section{Figure 4}

Bar charts showing densities at which contour buffer strips (CBS polygons $\mathrm{km}^{-2}$ of cropland) could be sited among 32 watersheds, arranged into Major Land Resource Areas (MLRA) and Agro-Hydrologic Landscape (AHL) groupings, with four watersheds per group. Geometric means are given for each group, and significant contrasts are indicated (refer to table 3 and figure $\mathbf{2}$ for key to comparison contrasts).

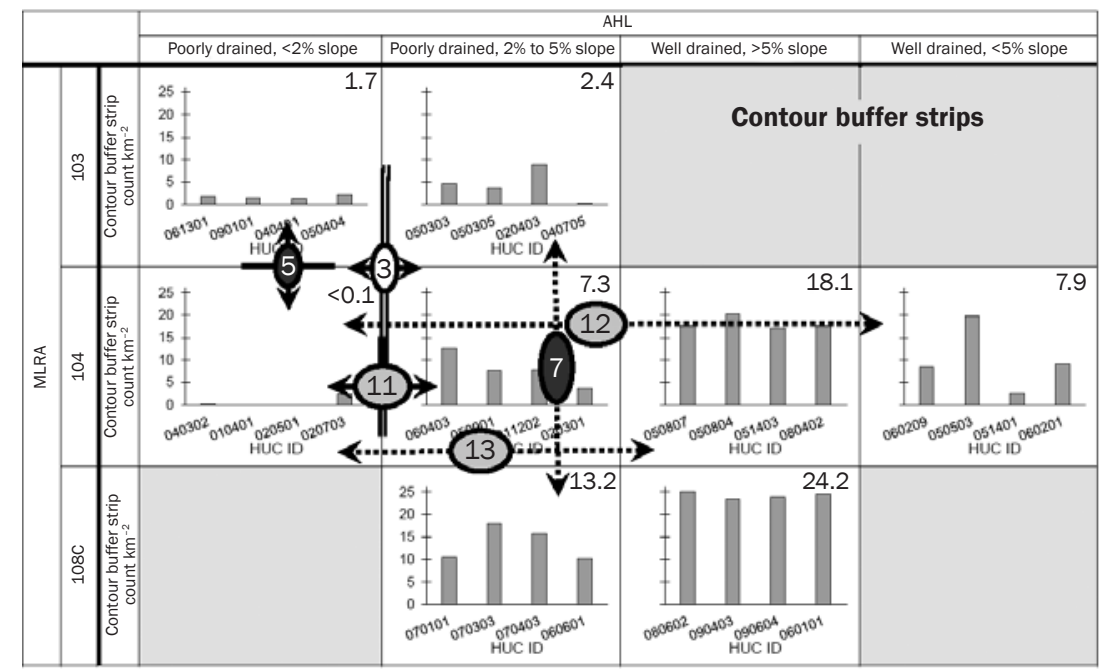

\section{Figure 5}

Bar charts of frequencies at which water and sediment control basins (count of water and sediment control basins [WASCOBs] km-2 of agricultural land) could be sited among 32 watersheds, arranged into Major Land Resource Areas (MLRA) and Agro-Hydrologic Landscape (AHL) groupings, with four watersheds per group. Geometric means are given for each group, and significant contrasts are indicated (refer to table 3 and figure 2 for key to comparison contrasts).

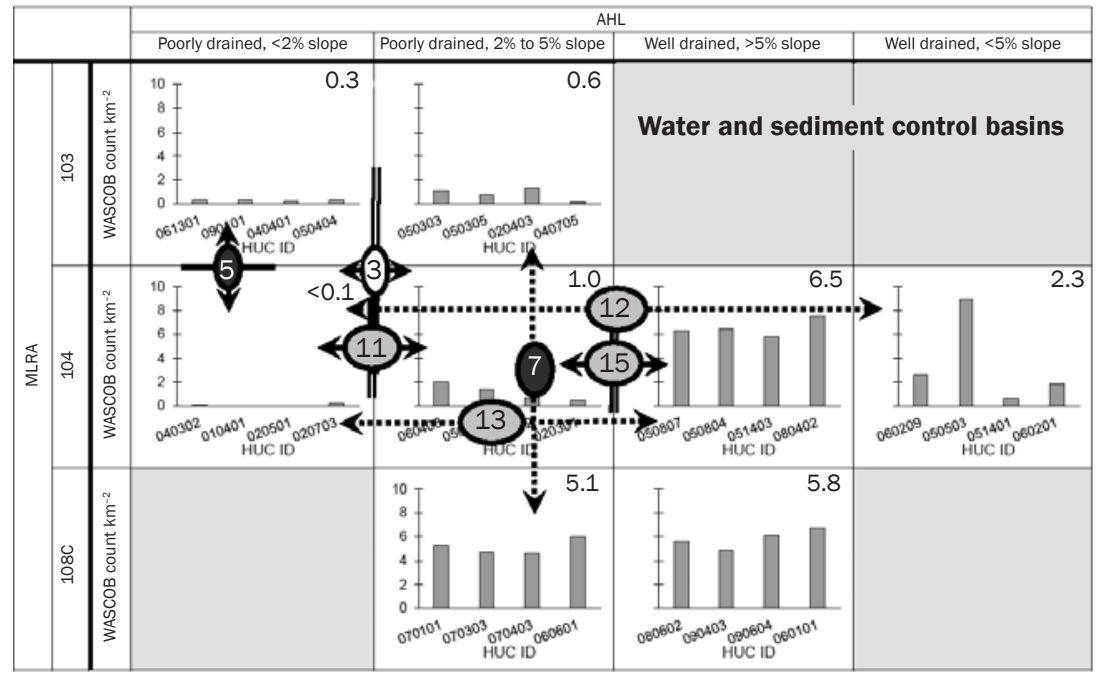

the landscape, and the ability to characterize landscapes in a way that conveys conservation opportunities could help planners more effectively address watershed improvement needs at regional scales. This study has been an exploration to determine if/how high-resolution data and GIS-based planning tools can be used to characterize conservation options from a regional perspective. Two landscape classification systems, MLRAs and AHLs, were included. We focused on how placement opportunities for four conser- vation practices (CD, CBS, WASCOBs, and GWWs) varied among landscape groupings. Results provided a mix of takeaways that we sum up below.

Controlled drainage could be most extensively implemented in PD $<2$ AHL watersheds. However, engineering designs to implement this practice would have to be more sophisticated in MLRA 103 due to the young, gently rolling terrain. In MLRA 108 , where tile drainage is least extensive, opportunities to implement CD may occur more frequently than expected, among those fields that are expected to be tile drained.

Contour buffer strips showed the fewest siting opportunities among PD $<2$ AHL watersheds, $<2.5 \mathrm{~km}^{-2}$ of cropland. The greatest potential rates of CBS implementation, $>17$ CBS polygons $\mathrm{km}^{-2}$, were found among the steepest (WD > $5 \mathrm{AHL}$ ) watersheds.

WASCOBs could most frequently be sited in MLRA 108C and WD > 5 AHL watersheds $\left(>10\right.$ practice placements $\mathrm{km}^{-2}$ ). However, for both CBS and WASCOB practices, there were examples where MLRAs showed significantly different rates of potential practice implementation within AHLs. Differences in slope shapes and landscape dissection among MLRAs create differences in conservation opportunities that may not be captured by drainage and slope classes of dominant soil map units (as captured by AHL designation).

The GWW tool in the ACPF, based on an SPI threshold approach, allows a high degree of flexibility in siting options. A tradeoff between contributing area and slope occurs that equalizes SPI distributions among the watersheds examined for this study. Results were influenced by land use as well as terrain, because the steeper areas of MLRA 108C are no longer farmed. In effect, agriculture has adapted to Iowa's landscapes. A process to place GWWs at a given density of GWWs on a watershed's cropland was suggested by considering exceedance percentages for a full range of SPI thresholds across 24 watersheds.

A key motivation for this study was to identify how regional planning strategies might be informed through studies like this one. However, it is difficult to present a simple message given the results reported here. A watershed planner's judgment, informed by local knowledge about the landscape and producer preferences, may often be critical in adapting precision conservation strategies to a given watershed. One clear conclusion, how- 
ever, is that edge-of-field conservation options were least extensive in MLRA 103, where CD systems may need more sophisticated engineering designs, opportunities to install WASCOBs and CBS practices are not common, and where riparian zones are fewer and farther between (given the low drainage density of streams in this MLRA). This suggests denitrifying practices (wetlands and bioreactors) should be emphasized in this region, along with environmentally conservative approaches to nutrient management. At the same time, options for placement of GWWs in MLRA 103 should be examined, particularly if effects of increasing precipitation trends on conservation outcomes are of concern.

In conclusion, both MLRA and AHL classes were useful in distinguishing conservation practice-placement opportunities among these watersheds. Landform characteristics, the actual extent of cropland in a watershed, and soil characteristics (slope and drainage classes) all contributed to elucidate conservation opportunities at watershed scale identified in this study. The need to consider local landscapes in detail as a part of conservation planning remains important. At the same time, these two landscape classification systems could be used together to develop effective regional conservation priorities for use of using precision conservation planning tools like the ACPF.

\section{Disclaimer}

Mention of trade names or commercial products in this publication is solely for the purpose of providing specific information and does not imply recommendation or endorsement by the US Department of Agriculture (USDA).

\section{Acknowledgements}

Development of the Agricultural Conservation Planning Framework was supported by a USDA interagency agreement between the Agricultural Research Service and the Natural Resources Conservation Service. Participation by Jarad Niemi, Iowa State University Department of Statistics, Ames, Iowa, was supported by the National Institute of Food and Agriculture, USDA, Hatch project number 1010162. USDA is an equal opportunity provider and employer.

\section{References}

Church, S.P., N. Babin, B. Bentlage, M. Dunn, J.D. Ulrich-

Schad, P. Ranjan, J. Magner, E. McLellan, S. Stephan, M.D.Tomer, and L.S. Prokopy. 2019.The Beargrass story: Utilizing social science to evaluate and learn from the “watershed approach." Journal of Contemporary Water Research and Education 167:78-96.

\section{Figure 6}

Stream Power Index (SPI) values at 2.0, 3.5, and 5.0 standard deviations (SD) above the watershed mean (diamonds, left axis); and associated exceedance percentages for croplands, plotted as geometric mean of four watersheds (gray bars, right axis) from each of eight landscape groupings. Contrasts 1, 5, and 6 are significant $(p<0.05)$ at 2.0 SDs, and Contrasts 2, 8, and 9 are significant at 5.0 SDs. See figure 2 for key to Contrasts. Interpretation: Differences in Agricultural Conservation Planning Framework (ACPF) grassed waterway placements among Major Land Resource Areas occur but depend on the SPI threshold selected.

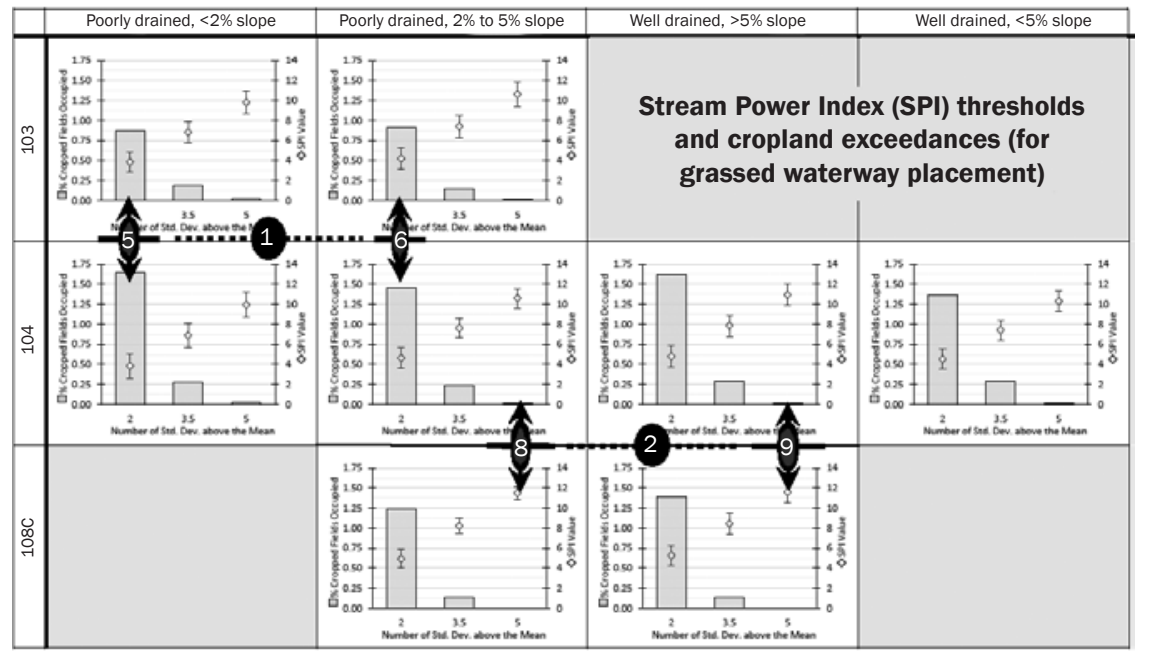

\section{Figure 7}

Linear influence of Stream Power Index (SPI) exceedance values on the density of grassed waterways obtained from the Agricultural Conservation Planning Framework (ACPF) grassed waterways tool (GWW), with $2 \mathrm{~m}$ grid DEMs. The inset graph shows the same data plotted on a log scale to better show how the data are separated according to the number of standard deviations selected as the SPI-exceedance threshold in the ACPF GWW tool (see text).

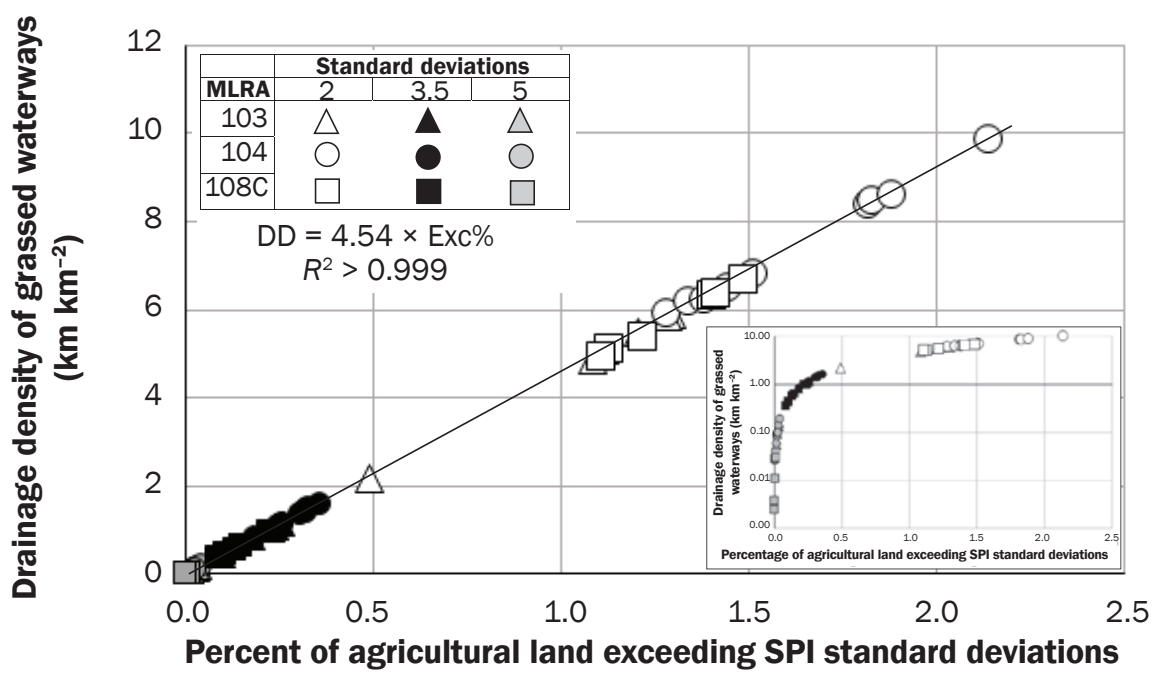

English River Watershed Management Authority. 2019. English River Watershed: ACPF. English River WMA. Kalona, IA: English River Watershed Management Authority. http://www.englishriverwma.org/acpf/.

Esri. 2017. ArcGIS products and support. Redlands, CA: Esri. https://www.esri.com.
Fiener, P., and K. Auerswald. 2003. Effectiveness of grassed waterways in reducing runoff and sediment delivery from agricultural watersheds. Journal of Environmental Quality 32(3):927-936.

Gali, R.K., M.L. Soupir, A.L. Kaleita, and P. Daggupati. 2015. Identifying potential locations for grassed 
waterways using terrain attributes and precision conservation technologies. Transactions of the ASABE 58(5):1231-1239

Gallant, A.L., T.R. Loveland, T.L. Sohl, and D.E. Napton. 2004. Using an ecoregion framework to analyze land cover and land use dynamics. Environmental Management 34(Suppl. 1):S89-S110.

Galzki, J.C., A.S. Birr, and D.J. Mulla. 2011. Identifying critical agricultural areas with three-meter LiDAR elevation data for precision conservation. Journal of Soil and Water Conservation 66(6):423-430, doi:10.2489/ jswc.66.6.423.

Iowa Soybean Association. 2019. Research publications and resources. Ankeny, IA. Iowa Soybean Association. https:// www.iasoybeans.com/programs/isa-research/publications/.

Konopacky, J., and L. Ristino. 2017. The healthy watershed framework: A blueprint for restoring nutrient-impaired watersheds through integrated Clean Water Act and Farm Bill conservation planning and implementation at the subwatershed level. Environmental Law 47:647.

Lewandowski, A., J. Moncrief, and M. Drewitz. 2006. The Minnesota Phosphorus Index: Assessing risk of phosphorus loss from cropland. St. Paul, MN: University of Minnesota Extension Service.

McLellan, E., K.E. Schilling, C.F. Wolter, M.D. Tomer, S.A Porter, J.A. Magner, D.R. Smith, and L.S. Prokopy. 2018. Right practice, right place: A conservation planning toolbox for meeting water quality goals in the Corn Belt. Journal of Soil and Water Conservation 73(2):29A34A, doi:10.2489/jswc.73.2.29A.

McMahon, G., S.M. Gregonis, S.W.Waltman, J.M. Olmernik, T.D. Thorson, J.A. Freeouf, A.H. Rorick, and J.E. Keys. 2001. Developing a spatial framework of common ecological regions for the conterminous United States. Environmental Management 28(3):293-316.

Mielke, L.N. 1985. Performance of water and sediment control basins in northeastern Nebraska. Journal of Soil and Water Conservation 40(6):524-528.

Norton, E.A. 1937. Provisional problem areas in soil conservation research in the United States. Soil Science Society of America Proceedings 1:495-504.

Olmernik, J.M. 1987. Ecoregions of the conterminous United States. Annals Association of American Geographers 77(1):118-125.

Olmernik, J.M., and G.E. Griffith. 2014. Ecoregions of the conterminous United States: Evolution of a hierarchical spatial framework. Environmental Management 54:1249-1266.

Pike, A.C., T.G. Mueller, A. Schorgendorfer, S.A. Shearer, and A.D. Karathansis. 2009. Erosion index derived from terrain attributes using logistic regression and neural networks. Agronomy Journal 101(5):1068-1079.

Porter, S.A., M.D. Tomer, D.E. James, and J.D. Van Horn. 2018. Agricultural Conservation Planning Framework ArcGIS Toolbox User's Manual, V 3. USDA Ames, IA: Agricultural Research Service National Laboratory for Agriculture and the Environment. www. acpf4watersheds.org/toolbox/.

Ranjan, P., A.S. Singh, M.D. Tomer, A.M. Lewandowski, and L.S. Prokopy. 2020. Farmer engagement using a precision approach to watershed-scale conservation planning: What do we know? Journal of Soil and Water Conservation, doi:10.2489/jswc.2020.00072.

Robertson, D.M., and D.A. Saad. 2003. Environmental water-quality zones for streams: A regional classification scheme. Environmental Management 31(5):581-602.

Rundhaug, T.J., G.R. Geimer, C.W. Drake, A.A. Amado, A.A. Bradley, C.F. Wolter, and L.J. Weber. 2018. Agricultural conservation practices in Iowa watersheds: Comparing actual implementation with practice potential. Environmental Monitoring and Assessment 190:659.

Salley, S.W., C.J. Talbot, and J.R. Brown. 2016. The Natural Resources Conservation Service land resource hierarchy and ecological sites. Soil Science Society of America Journal 80(1):1-9.

Schilling, K.E., C.F. Wolter, and E. McLellan. 2015. Agrohydrologic landscapes in the Upper Mississippi and Ohio River basins. Environmental Management 55:646-656.

Simon, A., and L. Klimetz. 2008. Relative magnitudes and sources of sediment in benchmark watersheds of the Conservation Effects Assessment Project. Journal of Soil and Water Conservation 63(6):504-522, doi:10.2489/ jswc.63.6.504.

Tarboton, D.G. 1997. A new method for the determination of flow directions and upslope areas in grid digital elevation models. Water Resources Research 33(2):309-319.

Tomer, M.D., K.M.B. Boomer, S.A. Porter, B.K. Gelder, D.E. James, and E. McLellan. 2015a. Agricultural Conservation Planning Framework: 2. Classification of riparian buffer design-types with application to assess and map stream corridors. Journal of Environmental Quality 44(3):768-779.

Tomer, M.D., W.G. Crumpton, R.L. Bingner, J.A. Kostel, and D.E. James. 2013a. Estimating nitrate load reductions from placing constructed wetlands in a HUC-12 watershed using LiDAR data. Ecological Engineering 56:69-78.

Tomer, M.D., D.E. James, and C.M.J. Sandoval-Green. 2017. Agricultural Conservation Planning Framework: 3. Land use and field boundary database development and structure. Journal of Environmental Quality 46(3):676-686.

Tomer, M.D., S.A. Porter, K.M.B. Boomer, D.E. James, J.A. Kostel, M.J. Helmers, T.M. Isenhart, and E. McLellan. 2015b.Agricultural Conservation Planning Framework: 1. Developing multi-practice watershed planning scenarios and assessing nutrient reduction potential. Journal of Environmental Quality 44(3):754-767.

Tomer, M.D., S.A. Porter, D.E. James, K.M.B. Boomer, J.A. Kostel, and E. McLellan. 2013b. Combining precision conservation technologies into a flexible framework to facilitate agricultural watershed planning. Journal of Soil and Water Conservation 68(5):113A-120A, doi:10.2489/ jswc.68.5.113A.

University of Northern Iowa. 2016. Iowa LiDAR Mapping Project. Cedar Falls, IA: University of Northern Iowa. http://www.geotree.uni.edu/lidar/.

USDA NRCS (Natural Resources Conservation Service). 2006. Land Resource Regions and Major Land Resource Areas of the United States, the Caribbean, and the Pacific Basin. USDA Handbook 296. Washington, DC: USDA Natural Resources Conservation Service.

USDA NRCS. 2017. National Conservation Practice Standards. Washington, DC: USDA Natural Resources Conservation Service. https://www.nrcs.usda.gov/wps/ portal/nrcs/main/national/technical/cp/ncps/.

Utah State University. 2015. TauDEM Version 5. Logan, UT: David Tarboton Hydrology Research Group, Utah State University. http://hydrology.usu.edu/taudem/taudem5/.

Williams, M.R., K.W. King, and N.R. Fausey. 2015. Drainage water management effects on tile drainage and water quality. Agricultural Water Management 148:43-51.

Wolock, D.M., T.C. Winter, and G. McMahon. 2004. Delineation and evaluation of Hydrologic-Landscape Regions in the United States using geographic information systems tools and multivariate statistical analyses. Environmental Management 34(Suppl 1):S71-S88.

Zhou, X., M.J. Helmers, H. Asbjornsen, R. Kolka, M.D. Tomer, and R.M. Cruse. 2014. Nutrient removal by prairie filter strips in agricultural landscapes. Journal of Soil and Water Conservation 69(1):54-64, doi:10.2489/ jswc.69.1.54.

Zimmerman, E.K., J.C. Tyndall, and L.A. Schulte. 2019. Using spatially targeted conservation to evaluate nitrogen reduction and economic opportunities for best management practice placement in agricultural landscapes. Environmental Management 64:313-328, https://doi.org/10.1007/s00267-019-01190-7. 